\title{
Shrews Soricidae of the Silesian Beskid Mountains
}

\author{
Robert W. MYSŁAJEK*, Sabina NOWAK* and Korneliusz KUREK** \\ *Association for Nature “Wolf”, Twardorzeczka 229, 34-324 Lipowa, Poland; e-mail: rwm@autograf.pl \\ **Faculty of Biology, University of Warsaw, Miecznikowa 1, 02-096 Warszawa, Poland; \\ e-mail: kornel.kurek@biol.uw.edu.pl,
}

\begin{abstract}
During a study conducted in 2002-2008 the following 6 species of shrews were recorded in the Silesian Beskid Mts. (Western Carpathians, S Poland): Sorex araneus, S. minutus, S. alpinus, Neomys fodiens, N. anomalus and Crocidura suaveolens. The most widespread was S. araneus (63.4\% of locations), followed by S. alpinus (13.4\%), S. minutus (12.2\%), $N$. fodiens (7.3\%), N. anomalus (2.4\%) and C. suaveolens (1.2\%). Among dead shrews (n=47) $S$. araneus comprised $56.6 \%$, S. minutus $21.7 \%$, S. alpinus $10.9 \%$, C. suaveolens $4.3 \%$, N. anomalus $4.3 \%$ and $N$. fodiens $2.2 \%$. During capture with live traps only $S$. araneus was recorded, constituting $2.5 \%$ of all small mammals captured. It was most frequently caught in deforested areas.
\end{abstract}

Key words: shrew fauna, Carpathians, mountains

\section{INTRODUCTION}

Diversity of mammal species in the Silesian Beskid Mountains is very unevenly documented (Witkowski 1997). There is relatively good knowledge regarding ungulates, carnivores and bats (Pucek \& Raczyński 1983, Nowak et al. 2005, Mysłajek et al. 2007), but small rodents and shrews still require more attention (Sagan 1950, Mysłajek \& Nowak 2003). Of the eight species of shrews (Soricidae) that occur in Poland (Pucek 1984) only four - Sorex araneus, S. minutus, S. alpinus and Neomys fodiens, have been recorded within the Silesian Beskid Mts. until now (Sagan 1950, Pucek \& Raczyński 1983).

The aim of our study was to complete the list of shrew species living in the Silesian Beskid Mountains.

\section{STUDY AREA}

The Silesian Beskid Mountains (SBM) are located in the western-most part of the Polish Carpathians (18 $59^{\prime}-19^{\circ} 07^{\prime} \mathrm{N}$; 49 $9^{\circ} 33^{\prime}-49^{\circ} 47^{\prime} \mathrm{E}$ ), and are divided into two parts - Polish (ca $560 \mathrm{~km}^{2}$ ) and Czech (ca $40 \mathrm{~km}^{2}$ ). Research was conducted only in the Polish part. Most of the area is protected as a landscape park $\left(386 \mathrm{~km}^{2}\right)$ established in 1998, and a major part $\left(263 \mathrm{~km}^{2}\right)$ was recently designated as a Natura 2000 site. There are also several nature reserves, but they cover only ca. $1 \%$ of the total area (Wilczek 2006).

The altitude within the study area ranges from 400 to $1257 \mathrm{~m}$ a.s.l. The climate of the SBM is mainly determined by altitude and is divided into three climatic zones: semi-warm (below $670 \mathrm{~m}$ a.s.l.), semi-cold (670-980 m a.s.l.) and cold (above $980 \mathrm{~m}$ a.s.l.) (Hess 1965, Table 1). Climatic zones correlate to plant zones. The lowest of these was formerly covered by rich forests dominated by oak (Quercus sp.) and lime (Tilia sp.). The forest cover has changed extensively and is presently dominated by farmland, villages, and towns. The middle zone was originally covered by beech (Fagus sylvatica) and fir (Abies alba) with an admixture of spruce (Picea alba), while the highest zone was dominated by natural spruce forests. Currently both the middle and highest zones are predominantly covered by planted spruce monocultures 
(Wilczek 2006). There are large meadows located within the forests, some are still used as pasture for livestock grazing, but the rest have not been grazed for a long time, and have subsequently been naturally re-colonized by young spruce, beech, and birch (Betula pendula) trees. There are numerous towns, villages, weekend cabins, and recreation centres along the forest peripheries as well as many ski lifts, ski routes, and tourist paths within the forest. Human penetration into the forest is the most intense during weekends and holidays (Mysłajek 2001). The average density of human population in the SBM is the highest in the Polish Carpathians, on average 150 inhabitants $/ \mathrm{km}^{2}$, and it reaches up to 300 inhabitants $/ \mathrm{km}^{2}$ near the town of Bielsko-Biała (Walaszek 2002).

Table 1. Characteristics of the climatic zones in the Silesian Beskid Mountains (according to Hess 1965).

\begin{tabular}{|l|c|c|c|c|c|}
\hline $\begin{array}{c}\text { Climatic } \\
\text { zones }\end{array}$ & $\begin{array}{c}\text { Elevation [m } \\
\text { a.s.l.] }\end{array}$ & $\begin{array}{c}\text { Average } \\
\text { temperature [ }{ }^{\circ} \mathrm{C} \text { ] }\end{array}$ & $\begin{array}{c}\text { Annual } \\
\text { precipitation [mm] }\end{array}$ & $\begin{array}{c}\text { Snow occurrence } \\
\text { [days] }\end{array}$ & $\begin{array}{c}\text { Length of vegetation } \\
\text { season [days] }\end{array}$ \\
\hline Cold & $>980$ & 2 & 1600 & 250 & 140 \\
Semi-cold & $670-980$ & 4 & 1400 & 210 & 170 \\
Semi-warm & $<670$ & $6-8$ & $800-1000$ & $110-165$ & $200-220$ \\
\hline
\end{tabular}

\section{METHODS}

The main method used to search the shrew fauna of the SBM was accidental collection of dead individuals, mainly killed and left uneaten by predators. In total we found 47 dead shrews between 2002-2008. We obtained additional data by capturing small mammals in live traps between 2004-2007. Wooden box traps baited with grain were originally set up to study rodents, so shrews were captured only occasionally. In main habitats occurring within the study area deciduous forests, coniferous forests and deforested areas (11 plots), distributed in every elevation zone, we set a line of 7-10 traps $10 \mathrm{~m}$ apart each other. Trapping was conducted in every September for 7 consecutive days. During 2389 'trap-nights' we captured 38 shrews. All collected and captured individuals were identified by external features and tooth characteristics according to the taxonomic key of Pucek (1984). We combined our data with published observations made in 1936-1938, which were obtained by capturing shrews with snap and pitfall traps (Sagan 1950). Altogether we analyzed 82 locations of 128 individual shrews within the SBM.

For each location of a given species we recorded: the latitude and longitude, the code of the Universal Transverse Mercator (UTM) grid, the elevation above sea level in metres. We obtained the position and altitude for every location in the field with GPS unit GPSMap 60CSx (Garmin, USA), while we derived the UTM grid by conversion of latitude and longitude with Gnomon software version 3.1 (Desmodus, Poland). For data published by Sagan (1950), we were able to define only an elevation and UTM grid, as the author has not used geographic coordinates, but only general descriptions of places.

\section{RESULTS}

In the SBM we recorded the following 6 species of Soricidae - Sorex araneus Linnaeus, 1758; Sorex alpinus Schinz, 1837; Sorex minutus Linnaeus, 1758; Neomys fodiens (Pennant, 1771); Neomys anomalus (Cabrera, 1907) and Crocidura suaveolens (Pallas, 1811). Shrews were recorded at 82 locations presented in Appendix 1.

$S$. araneus was the most widespread species in the SBM, accounting for $63.4 \%$ of known shrew locations. It was followed by S. alpinus (13.4\%) and S. minutus (12.2\%), N. fodiens (7.4\%), N. anomalus (2.4\%) and C. suaveolens (1.2\%) (Appendix 1).

Among dead shrews found within the SBM $(n=47)$ the dominant species was $S$. araneus (56.6\%), also common were S. minutus (21.7\%) and S. alpinus (10.9\%), while the remaining three species were sparse $-C$. suaveolens (4.3\%), $N$. anomalus (4.3\%) and $N$. fodiens (2.2\%). 
In the case of $C$. suaveolens, the only location found was near buildings in a village, where two adults were killed by a cat. We also discovered a nest with four young below plastic foil covering a small heap of gravel at the same location.

During capture with live traps, we caught 1510 small terrestrial mammals. However shrews, solely $S$. araneus, constituted only $2.5 \%$ of them (38 individuals). We captured $S$. araneus most frequently in deforested areas (meadows and clearcuts), while it was rarely trapped in all types of deciduous forests (beech, oak and riparian forests) (Table 2).

Table 2. Common shrews Sorex araneus caught with live traps in main habitats within climatic zones in the Silesian Beskid Mountains 2004-2007. Recalculated to number of individuals per 100 trap-nights.

\begin{tabular}{|l|c|c|c|c|}
\hline \multicolumn{1}{|c|}{ Habitat type } & Semi-warm zone & Semi-cold zone & Cold zone & Average \\
\hline Deforested areas & 3.5 & 1.8 & 5.0 & 3.4 \\
Deciduous forests & 0.0 & 0.5 & - & 0.1 \\
Coniferous forests & 0.5 & 0.9 & 1.8 & 1.1 \\
\hline Average & 1.2 & 1.1 & 3.4 & 1.6 \\
\hline
\end{tabular}

\section{DISCUSSION}

Although there are many methods for the census of small mammals (Krebs 2006), the species composition of shrew fauna has mostly been studied by trapping and analysis of owl pellets (e.g. Bryja \& Rehák 1998, Górecki et al. 2000). During trapping effort, shrews show preferences for pitfall traps and are rarely captured with either live or snap traps (Pucek 1969). The collection of dead individuals we used in order to assess species composition of shrew fauna is rarely used as a research method because it is considered very labour intensive. However, dead shrews can frequently be found, as they are often killed and left uneaten by mammalian predators (Jędrzejewska \& Jędrzejewski 1998).

In comparison with data on shrew fauna of the SBM obtained in 1936-1938 (Sagan 1950), we recorded two additional species $-N$. anomalus and $C$. suaveolens. Altogether, the shrew fauna of the Silesian Beskid Mts. includes 6 out of 8 shrew species of Poland (Pucek 1984). This is probably a complete list of species occurring within SBM. Amongst the remaining shrew species, Sorex caecutiens Laxmann, 1788 was recorded exclusively in the Białowieża Forest (Pucek \& Raczyński 1983, Pucek 2001a), while Crocidura leucodon (Hermann, 1780) occurs in south-east Poland and has not been recorded in areas adjacent to the SBM until now (Chudoba \& Haitlinger 1971, Pucek \& Raczyński 1983, Adamski 1996, Bryja \& Rehák 1998, Bryja et al. 2002, Wołoszyn \& Postawa 2003).

The shrew fauna of the SBM is heavily dominated by the Sorex genera, especially by $S$. araneus. Such a pattern was observed in the most of the mountain ranges of the Polish Carpathians (Chudoba \& Humiński 1968, Chudoba \& Haitlinger 1971, Adamski 1996, Górecki et al. 2000, Taborska 2004). S. araneus was captured with higher frequency in deforested areas such as clearcuts and meadows. This can be explained by the higher availability of soil invertebrates, mainly earthworms, in such environments (Rożen \& Mysłajek 2005), which form a substantial part of the diet of S. araneus (Churchfield 1982, Churchfield \& Rychlik 2006). S. minutus occurs in every mountain range in Poland, where it can be quite abundant (Chudoba \& Haitlinger 1971). In the SBM it was rarely found above $1000 \mathrm{~m}$ a.s.l., contrary to the neighbouring mountain ranges, where it constituted up to $22.7 \%$ of captured individuals in areas of higher elevation (Chudoba \& Haitlinger 1971). In Poland, S. alpinus occurs exclusively in mountains - the Carpathians and Sudetes (Pucek \& Raczyński 1983), and can be relatively numerous in some locations (Haitlinger \& Humiński 1964). The lowest recorded location for this species was at $600 \mathrm{~m}$ a.s.l. (Sagan 1950, this study), but in the neighbouring Beskid Żywiecki Mts. it was also found at $500 \mathrm{~m}$ a.s.l (Chudoba \& Haitlinger 1971). 
Similarly to Sagan (1950), we confirmed occurrence of $N$. fodiens only in the lowest climatic zone, while $N$. anomalus occurs also at higher elevations. However, in European mountains both species have been recorded far above elevations where we observed them within the SBM (Mitchell-Jones et al. 1999), and due to the small sample size collected by us we were unable to define their altitudinal distribution in this area.

We observed only a few individuals of $C$. suaveolens in the SBM, all of them at the same low elevation location near buildings. This species is frequently observed in the neighbourhood of human settlements, near buildings, around irrigation channels, at the edges of fields, and walls or fences surrounding houses (Tez 2000). It is rarely observed at higher elevations. However, in Poland, it was recorded up to $1250 \mathrm{~m}$ a.s.l., e.g. near the tourist shelter in the Beskid Żywiecki Mts. (Haitlinger 1967). The SBM are densely inhabited by people and there are many buildings at higher elevations (Mysłajek 2001), that could provide suitable conditions for C. suaveolens.

Among the taxa we recorded in the SBM, the most valuable from the conservation point of view is the occurrence of both $N$. anomalus and S. alpinus. They are not globally endangered (Stone 1995), but their conservation is regionally important. N. anomalus is included in the Polish Red Data Book (Pucek 2001b) and is protected by the Bern Convention, while S. alpinus is mentioned as near threatened by IUCN Red List of Threatened Species Regional Assessment for Europe (Temple \& Terry 2007).

\section{ACKNOWLEDGMENTS}

This study was supported by the budget of the Association for Nature "Wolf". Many volunteers helped us during the project, and we are particularly grateful to P. Orysiak, M. Figura and T. Jonderko. We would also like to thank R. Morley for linguistic advice.

\section{REFERENCES}

ADAMSKI P. 1996. Drobne ssaki partii szczytowej masywu Pilska oraz ocena wpływu ruchu turystycznego na teriofaunę. In: ŁAJCZAK A., MiCHALIK S. \& WITKOWSKI Z. (eds), Wpływ narciarstwa i turystyki pieszej na przyrodę masywu Pilska, pp. 197-203. Studia Naturae 41, Instytut Ochrony Przyrody PAN, Kraków, 253 pp.

BRYJA J. \& REHÁK Z. 1998. Small mammals in the Protected Landscape Area of Poodř́ and its vicinity: I. Insectivora, Rodentia. Časopis Slezského Zemského Muzea (A) 47: 123-131.

BRYJA J., HEROLDOVÁ M. \& ZEJDA J. 2002. Effects of deforestation on structure and diversity of small mammal communities in the Moravskoslezské Beskydy Mts (Czech Republic). Acta Theriologica 47: 295-306.

CHUdOBA S. \& HumiŃSKi S. 1968. Owadożerne i gryzonie Beskidu Sądeckiego. Acta zoologica cracoviensia 8: $213-230$.

CHudoba S. \& HAitlinger R. 1971. Drobne ssaki Beskidu Żywieckiego. Acta zoologica cracoviensia 8: $413-434$.

CHURCHFIELD S. 1982. Food availability and the diet of the common shrew, Sorex araneus, in Britain. Journal of Animal Ecology 51: 15-28.

ChuRChFIELD S. \& RYCHLIK L. 2006. Diets and coexistence in Neomys and Sorex shrews in Białowieża Forest, eastern Poland. Journal of Zoology, London 269: 381-390.

GóRECKI A., ĆWIKOWSKI C., GRYC A. \& JABŁOŃSKA I. 2000. Drobne ssaki Bieszczadów. Monografie Bieszczadzkie 9: 71-90.

HAitLinger R. 1967. Wysokogórskie stanowisko Crocidura suaveolens (Pall.). Przegląd zoologiczny 11, 3: 349-350.

HAitlinger R. \& HumińSKi S. 1964. Sorex alpinus Schinz, 1837 (Mammalia, Soricidae) w Polsce. Acta Theriologica 9, 8: 111-123.

HESS M. 1965. Piętra klimatyczne w polskich Karpatach Zachodnich. Zeszyty Naukowe Uniwersytetu Jagiellońskiego 115, Prace Geograficzne 11: 1-267.

JĘDRZEJEWSKA B. \& JEDRZEJEWSKI W. 1998. Predation in the vertebrate communities. The Białowieża Primeval Forest as a case study. Springer Verlag, New York-Berlin, $450 \mathrm{pp.}$

KreBs C. 2006. Mammals. In: SutherLAND W. J. (ed.). Ecological census techniques, pp. 351-369. Cambridge University Press, Cambridge, 432 pp.

Mitchell-Jones A. J., AMORi G., BogDANOWICZ W., KRYŠTUFEK B., REIJNDERS P. J. H., SPITZENBERGER F., STUBBE M., Thissen J. B. M., Vohralík V. \& Zima J. 1999. The atlas of European mammals. T \& AD Poyser Ltd, London, 484 pp. 
MYSŁAJEK R. W. 2001. Możliwości rozwoju różnych form turystyki w zachodniej części Karpat - na przykładzie Nadleśnictwa Węgierska Górka. Przegląd Przyrodniczy 12: 115-126.

MySŁAJEK R. W. \& NowAK S. 2003. Stanowiska koszatki i orzesznicy w Parku Krajobrazowym Beskidu Śląskiego. Chrońmy Przyrodę Ojczystą 2: 145-147.

MystajeK R. W., KureK K., SzUra C., NowAK S. \& OrysiaK P. 2007. Bats (Chiroptera) of the Silesian Beskid Mountains. Fragmenta Faunistica 50: 77-85.

NowAK S., MYsŁAJEK R. W. \& JĘDRZEJEWSKA B. 2005. Patterns of wolf Canis lupus predation on wild and domestic ungulates in the Western Carpathian Mountains (S Poland). Acta Theriologica 50: 263-276.

PUCEK Z. 1969. Trap response and estimation of numbers of shrews in removal catches. Acta Theriologica 14, $28: 403-426$.

PUCEK Z. 1984. Klucz do oznaczania ssaków Polski. PWN, Warszawa, 384 pp.

PuCEK Z. 2001a. Sorex caecutiens. In: GŁowACiŃSKi Z. (ed.), Polska Czerwona Księga Zwierząt. Kręgowce, pp. 4142. PWRiL, Warszawa, 452 pp.

PUCEK Z. 2001b. Neomys anomalus. In: GŁOWACIŃSKi Z. (ed.), Polska Czerwona Księga Zwierząt. Kręgowce, pp. 4244. PWRiL, Warszawa, $452 \mathrm{pp}$.

PUCEK Z. \& RACZYŃSKi J. (eds). 1983. Atlas rozmieszczenia ssaków w Polsce. PWN, Warszawa, 188 pp.

RoŻen A. \& MYSŁAJEK R. W. 2005. Earthworm communities of the Silesian Beskid Mountains. In: PoP V. V. \& PoP A. A. (eds), Advances in Earthworm Taxonomy II (Annelida: Oligochaeta), pp. 195-202. Cluj University Press, Cluj, 220 pp.

SAGAN L. 1950. Przyczynek do badań nad drobnymi ssakami (Micromammalia) Beskidu Śląskiego (Karpaty Zachodnie). In: Rejmont-Grochowska I., SAgAn L., Mikulska I., Mikulski J. S. \& Toll S. (eds), Studia nad florą i fauną Beskidu Śląskiego, pp. 73-110. Wydawnictwa Śląskie, Prace Biologiczne 2, Polska Akademia Umiejętności, Kraków, 205 pp.

StOne R. D. (comp.). 1995. Eurasian Insectivores and Tree Shrews. Status Survey and Conservation Action Plan. IUCN/SSC Insectivore, Tree Shrew and Elephant Shrew Specialist Group, Gland, 108 pp.

TABORSKA M. 2004. Small mammals of the Wołosate area (Bieszczady National Park, SE Poland). Acta zoologica cracoviensia 47: 49-59.

Temple H. J. \& Terry A. (comp.). 2007. The Status and Distribution of European Mammals. Office for Official Publications of the European Communities, Luxembourg, $48 \mathrm{pp}$.

TEZ C. 2000. Taxonomy and distribution of the white-toothed shrews (Crocidura) (Soricidae: Insectivora: Mammalia) of Turkey. Turkish Journal of Zoology 24: 365-374.

WALASZEK B. (ed.). 2002. Rocznik statystyczny województwa śląskiego. Urząd Statystyczny w Katowicach, Katowice, 267 pp.

WILCZEK Z. 2006. Fitosocjologiczne uwarunkowania ochrony przyrody Beskidu Śląskiego (Karpaty Zachodnie). Wydawnictwo Uniwersytetu Śląskiego, Katowice, 223 pp.

WITKOWSKI Z. 1997. Stan poznania, zagrożenia i ochrona fauny województwa bielskiego. In: MiKOŁAJSKI J. \& SOŁTYSIK J. (eds). Przyroda województwa bielskiego, pp. 139-191. Colgraf Press, Poznań, 280 pp.

WoŁoszYN B. W. \& PostaWA T. 2003. Drobne ssaki: owadożerne, nietoperze i gryzonie (Insectivora, Chiroptera, Rodentia) masywu Babiej Góry. In: WoŁoszyn B. W., WoŁoszyn D. \& CELARY W. (eds), Monografia fauny Babiej Góry, pp. 441-463. Komitet Ochrony Przyrody PAN, Kraków, 489 pp.

\section{STRESZCZENIE}

\section{[Ryjówki (Soricidae) Beskidu Śląskiego]}

W Beskidzie Śląskim stwierdzono występowanie 6 gatunków ryjówek. Były to: ryjówka aksamitna Sorex araneus Linnaeus, 1758, ryjówka malutka Sorex minutus Linnaeus, 1758, ryjówka górska Sorex alpinus Schinz, 1837, rzęsorek rzeczek Neomys fodiens (Pennant, 1771), rzęsorek mniejszy Neomys anomalus (Cabrera, 1907) i zębiełek karliczek Crocidura suaveolens (Pallas, 1811). Najczęściej notowana była ryjówka aksamitna (63,4\% stanowisk), następnie ryjówka alpejska (13,4\%), ryjówka malutka (12,2\%), rzęsorek rzeczek (7,3\%), rzęsorek mniejszy $(2,4 \%)$ i zębiełek karliczek (1,2\%) (Appendix 1). Wśród martwych ryjówek odnalezionych w Beskidzie Śląskim $(\mathrm{n}=47)$ S. araneus stanowił $56,6 \%$, S. minutus $21,7 \%$, S. alpinus $10,9 \%$, C. suaveolens $4,3 \%, N$. anomalus $4,3 \%$ a $N$. fodiens $2,2 \%$. W trakcie odłowów w drewniane pułapki żywołowne rejestrowano wyłącznie ryjówkę aksamitną, która była najczęstsza na powierzchniach bezleśnych (Tab. 2). 
Appendix 1. Locations of shrews in the Silesian Beskid Mountains. For data derived from Sagan (1950) only the UTM grid and elevation were available

\begin{tabular}{|c|c|c|c|c|}
\hline 1 & 2 & 3 & 4 & 5 \\
\hline Species & Latitude N & Longitude E & UTM grid & Elevation [m a.s.l.] \\
\hline Crocidura suaveolens & $49^{\circ} 39^{\prime} 30^{\prime \prime}$ & $19^{\circ} 05^{\prime} 33^{\prime \prime}$ & CA60 & 530 \\
\hline Neomys anomalus & $\begin{array}{l}49^{\circ} 40^{\prime} 11^{\prime \prime} \\
49^{\circ} 37^{\prime} 52^{\prime \prime}\end{array}$ & $\begin{array}{l}19^{\circ} 00^{\prime} 34^{\prime \prime} \\
19^{\circ} 03^{\prime} 41^{\prime \prime}\end{array}$ & $\begin{array}{l}\text { CA50 } \\
\text { CV59 } \\
\end{array}$ & $\begin{array}{l}1110 \\
870\end{array}$ \\
\hline Neomys fodiens & $49^{\circ} 39^{\prime} 42^{\prime \prime}$ & $19^{\circ} 03^{\prime} 22^{\prime \prime}$ & $\begin{array}{l}\text { CA40 } \\
\text { CA51 } \\
\text { CA51 } \\
\text { CA51 } \\
\text { CA51 } \\
\text { CA50 }\end{array}$ & $\begin{array}{l}450 \\
650 \\
600 \\
550 \\
500 \\
570\end{array}$ \\
\hline Sorex alpinus & $\begin{array}{l} \\
49^{\circ} 37^{\prime} 07^{\prime \prime} \\
49^{\circ} 39^{\prime} 10^{\prime \prime} \\
49^{\circ} 39^{\prime} 10^{\prime \prime} \\
49^{\circ} 40^{\prime} 32^{\prime \prime} \\
49^{\circ} 37^{\prime} 09^{\prime \prime} \\
49^{\circ} 38^{\prime} 54^{\prime \prime}\end{array}$ & $\begin{array}{l}19^{\circ} 00^{\prime} 54^{\prime \prime} \\
19^{\circ} 02^{\prime} 40^{\prime \prime} \\
19^{\circ} 02^{\prime} 40^{\prime \prime} \\
19^{\circ} 02^{\prime} 44^{\prime \prime} \\
19^{\circ} 04^{\prime} 03^{\prime \prime} \\
19^{\circ} 04^{\prime} 30^{\prime \prime}\end{array}$ & $\begin{array}{l}\text { CV59 } \\
\text { CV59 } \\
\text { CV59 } \\
\text { CV59 } \\
\text { CA51 } \\
\text { CV59 } \\
\text { CA50 } \\
\text { CA50 } \\
\text { CA50 } \\
\text { CV69 } \\
\text { CA60 }\end{array}$ & $\begin{array}{l}780 \\
900 \\
900 \\
900 \\
650 \\
1070 \\
600 \\
600 \\
950 \\
1030 \\
520\end{array}$ \\
\hline Sorex araneus & $\begin{array}{l}\text { " } \\
49^{\circ} 41^{\prime} 20^{\prime \prime} \\
49^{\circ} 37^{\prime} 44^{\prime \prime} \\
\\
\\
\\
49^{\circ} 39^{\prime} 56^{\prime \prime} \\
49^{\circ} 37^{\prime} 58^{\prime \prime} \\
49^{\circ} 39^{\prime} 03^{\prime \prime} \\
49^{\circ} 39^{\prime} 10^{\prime \prime} \\
49^{\circ} 40^{\prime} 33^{\prime \prime} \\
49^{\circ} 39^{\prime} 36^{\prime \prime} \\
49^{\circ} 40^{\prime} 31^{\prime \prime} \\
49^{\circ} 37^{\prime} 45^{\prime \prime} \\
49^{\circ} 40^{\prime} 32^{\prime \prime} \\
49^{\circ} 37^{\prime} 43^{\prime \prime} \\
49^{\circ} 39^{\prime} 11^{\prime \prime} \\
49^{\circ} 40^{\prime} 24^{\prime \prime} \\
49^{\circ} 40^{\prime} 23^{\prime \prime} \\
49^{\circ} 38^{\prime} 26^{\prime \prime} \\
49^{\circ} 40^{\prime} 26^{\prime \prime} \\
49^{\circ} 39^{\prime} 44^{\prime \prime} \\
49^{\circ} 38^{\prime} 52^{\prime \prime}\end{array}$ & $\begin{array}{l}18^{\circ} 57^{\prime} 29^{\prime \prime} \\
18^{\circ} 58^{\prime} 36^{\prime \prime} \\
\\
19^{\circ} 00^{\prime} 31^{\prime \prime} \\
19^{\circ} 00^{\prime} 36^{\prime \prime} \\
19^{\circ} 00^{\prime} 50^{\prime \prime} \\
19^{\circ} 00^{\prime} 59^{\prime \prime} \\
19^{\circ} 01^{\prime} 05^{\prime \prime} \\
19^{\circ} 01^{\prime} 56^{\prime \prime} \\
19^{\circ} 02^{\prime} 29^{\prime \prime} \\
19^{\circ} 02^{\prime} 37^{\prime \prime} \\
19^{\circ} 02^{\prime} 37^{\prime \prime} \\
19^{\circ} 02^{\prime} 45^{\prime \prime} \\
19^{\circ} 02^{\prime} 45^{\prime \prime} \\
19^{\circ} 02^{\prime} 47^{\prime \prime} \\
19^{\circ} 02^{\prime} 49^{\prime \prime} \\
19^{\circ} 02^{\prime} 57^{\prime \prime} \\
19^{\circ} 03^{\prime} 03^{\prime \prime} \\
19^{\circ} 03^{\prime} 05^{\prime \prime} \\
19^{\circ} 03^{\prime} 06^{\prime \prime}\end{array}$ & $\begin{array}{l}\text { CA40 } \\
\text { CA40 } \\
\text { CA40 } \\
\text { CA40 } \\
\text { CA40 } \\
\text { CV49 } \\
\text { CV59 } \\
\text { CA50 } \\
\text { CV59 } \\
\text { CV59 } \\
\text { CV59 } \\
\text { CV59 } \\
\text { CV59 } \\
\text { CA51 } \\
\text { CV59 } \\
\text { CV59 } \\
\text { CA50 } \\
\text { CV59 } \\
\text { CV59 } \\
\text { CA50 } \\
\text { CA51 } \\
\text { CA50 } \\
\text { CA50 } \\
\text { CA51 } \\
\text { CA50 } \\
\text { CA50 } \\
\text { CV59 } \\
\text { CA50 } \\
\text { CV59 } \\
\text { CA50 } \\
\text { CA50 } \\
\text { CA50 } \\
\text { CV59 } \\
\text { CA50 } \\
\text { CA50 } \\
\text { CA50 }\end{array}$ & $\begin{array}{l}550 \\
550 \\
600 \\
450 \\
550 \\
700 \\
780 \\
950 \\
1000 \\
899 \\
900 \\
700 \\
850 \\
1050 \\
800 \\
900 \\
1150 \\
1053 \\
1200 \\
950 \\
600 \\
990 \\
1150 \\
550 \\
796 \\
960 \\
1090 \\
960 \\
1070 \\
600 \\
830 \\
880 \\
990 \\
930 \\
580 \\
880 \\
\end{array}$ \\
\hline
\end{tabular}




\begin{tabular}{|c|c|c|c|c|}
\hline 1 & 2 & 3 & 4 & 5 \\
\hline & $49^{\circ} 37^{\prime} 43^{\prime \prime}$ & $19^{\circ} 03^{\prime} 11^{\prime \prime}$ & CV59 & 1020 \\
\hline & $49^{\circ} 39^{\prime} 29^{\prime \prime}$ & $19^{\circ} 03^{\prime} 11^{\prime \prime}$ & CA50 & 575 \\
\hline & $49^{\circ} 39^{\prime} 27^{\prime \prime}$ & $19^{\circ} 03^{\prime} 14^{\prime \prime}$ & CA50 & 600 \\
\hline & $49^{\circ} 39^{\prime} 43^{\prime \prime}$ & $19^{\circ} 03^{\prime} 33^{\prime \prime}$ & CA50 & 575 \\
\hline & $49^{\circ} 37^{\prime} 39^{\prime \prime}$ & $19^{\circ} 03^{\prime} 46^{\prime \prime}$ & CV59 & 980 \\
\hline & $49^{\circ} 39^{\prime} 47^{\prime \prime}$ & $19^{\circ} 03^{\prime} 47^{\prime \prime}$ & CA60 & 550 \\
\hline & $49^{\circ} 37^{\prime} 53^{\prime \prime}$ & $19^{\circ} 03^{\prime} 58^{\prime \prime}$ & CV69 & 942 \\
\hline & $49^{\circ} 42^{\prime} 46^{\prime \prime}$ & $19^{\circ} 04^{\prime} 00^{\prime \prime}$ & CA60 & 520 \\
\hline & $49^{\circ} 38^{\prime} 54^{\prime \prime}$ & $19^{\circ} 04^{\prime} 33^{\prime \prime}$ & CA60 & 633 \\
\hline & $49^{\circ} 38^{\prime} 06^{\prime \prime}$ & $19^{\circ} 04^{\prime} 37^{\prime \prime}$ & CV69 & 952 \\
\hline & $49^{\circ} 39^{\prime} 06^{\prime \prime}$ & $19^{\circ} 04^{\prime} 48^{\prime \prime}$ & CA60 & 600 \\
\hline & $49^{\circ} 40^{\prime} 01^{\prime \prime}$ & $19^{\circ} 05^{\prime} 20^{\prime \prime}$ & CA60 & 505 \\
\hline & $49^{\circ} 39^{\prime} 46^{\prime \prime}$ & $19^{\circ} 05^{\prime} 20^{\prime \prime}$ & CA60 & 517 \\
\hline & $49^{\circ} 39^{\prime} 29^{\prime \prime}$ & $19^{\circ} 05^{\prime} 33^{\prime \prime}$ & CA60 & 530 \\
\hline & $49^{\circ} 39^{\prime} 43^{\prime \prime}$ & $19^{\circ} 05^{\prime} 38^{\prime \prime}$ & CA60 & 530 \\
\hline & $49^{\circ} 39^{\prime} 37^{\prime \prime}$ & $19^{\circ} 05^{\prime} 47^{\prime \prime}$ & CA60 & 520 \\
\hline Sorex minutus & $49^{\circ} 41^{\prime} 21^{\prime \prime}$ & $18^{\circ} 53^{\prime} 27^{\prime \prime}$ & CA40 & 680 \\
\hline & & & CV59 & 700 \\
\hline & $49^{\circ} 36^{\prime} 51^{\prime \prime}$ & $19^{\circ} 02^{\prime} 15^{\prime \prime}$ & CV59 & 730 \\
\hline & $49^{\circ} 38^{\prime} 25^{\prime \prime}$ & $19^{\circ} 02^{\prime} 56^{\prime \prime}$ & CV59 & 990 \\
\hline & $49^{\circ} 39^{\prime} 44^{\prime \prime}$ & $19^{\circ} 02^{\prime} 57^{\prime \prime}$ & CA50 & 580 \\
\hline & $49^{\circ} 39^{\prime} 44^{\prime \prime}$ & $19^{\circ} 03^{\prime} 01^{\prime \prime}$ & CA50 & 580 \\
\hline & $49^{\circ} 39^{\prime} 45^{\prime \prime}$ & $19^{\circ} 03^{\prime} 12^{\prime \prime}$ & CA50 & 565 \\
\hline & $49^{\circ} 42^{\prime} 30^{\prime \prime}$ & $19^{\circ} 03^{\prime} 23^{\prime \prime}$ & CA50 & 571 \\
\hline & $49^{\circ} 39^{\prime} 09^{\prime \prime}$ & $19^{\circ} 03^{\prime} 48^{\prime \prime}$ & CA60 & 920 \\
\hline & $49^{\circ} 39^{\prime} 30^{\prime \prime}$ & $19^{\circ} 05^{\prime} 33^{\prime \prime}$ & CA60 & 530 \\
\hline
\end{tabular}

